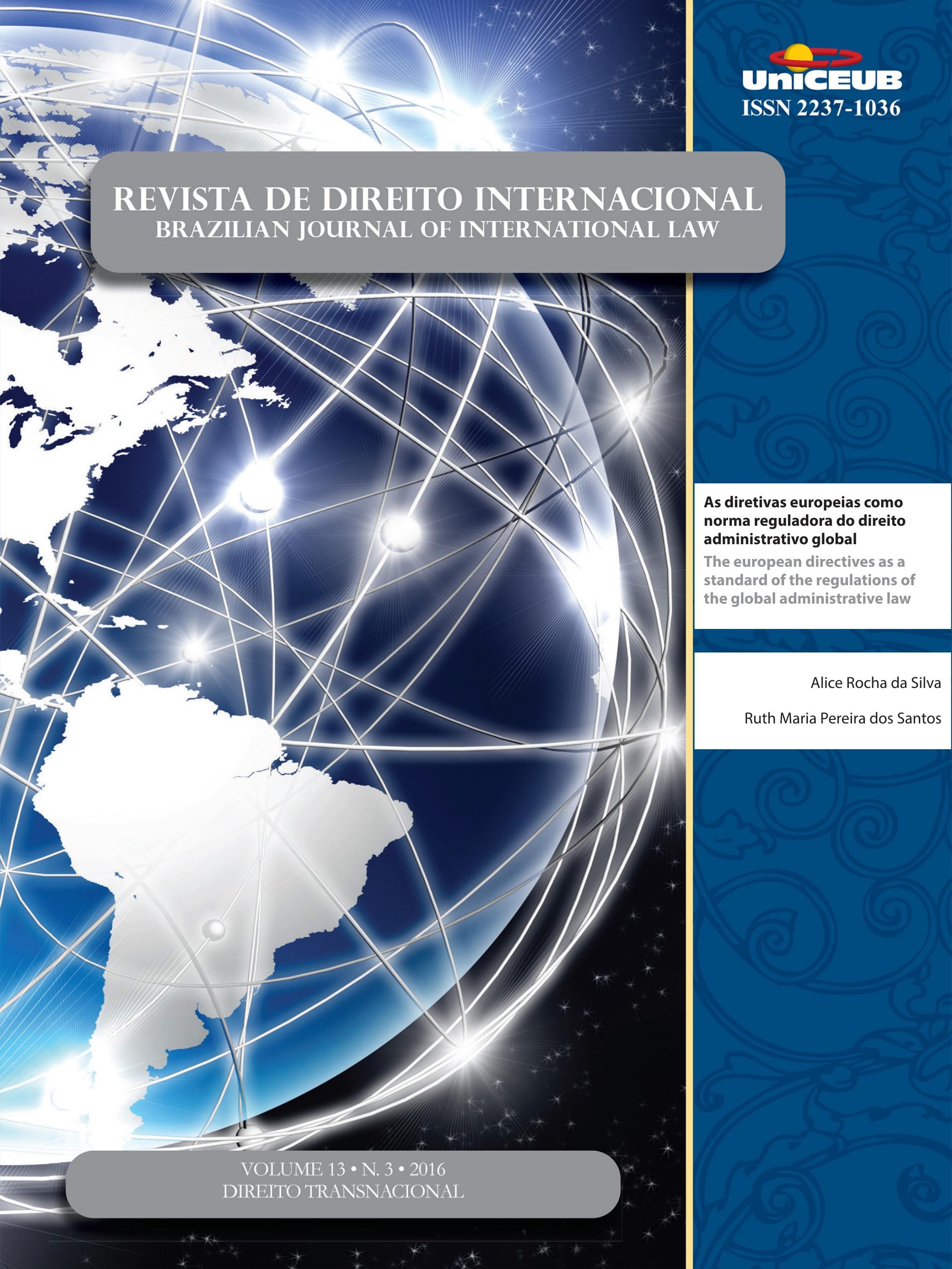


Crônicas da ATUALIdAde do direito internacional .................................................. 2

I. Dossiê Temático: Direito Transnacional .........................................................15

EDITORIAL: O Direito Transnacional - Circulação de normas e relações jurídicas transnacionais .......16 Priscila Pereira de Andrade

A emergênCia do direito transnacional ambiental .............................................18 Priscila Pereira de Andrade

Desafíos y RESPUESTAS TRANSNACIONALES FRENTE A LOS CRÍMENES AMBIENTALES ...............30 Rosmerlin Estupiñan-Silva

DiREITO TRANSNACIONAL E MUdANÇAS CLIMÁTICAS .50 Géraud de Lassus Saint-Geniès

Especies en movimiento: la Convención sobre el Comercio Internacional de Especies Amenazadas de Fauna y Flora Silvestres como espacio de “Encuentro” de discursos, ACTORES Y ESTRATEGIAS EN EL DERECHO AMBIENTAL TRASNACIONAL

María Valeria Berros e Dabel Leandro Franco

El carácter transnacional del Sistema comunitario de ECogestion « Eco-ManageMENT AND Audit SCHEME » (EMAS) DENTRo de LA UE y MÁs ALlÁ DE SUS Fronteras ......72 Adélie Pomade

O CONCEITO DE CONDUTA EMPRESARIAL RESPONSÁVEL À LUZ DOS ORDENAMENTOS JURÍDICOS BRASILEIRO, INTERNACIONAL E TRANSNACIONAL

Gabriel Webber Ziero

ARBITRAGEM NO DIREITO TRIBUTÁRIO INTERNACIONAL E NO DIREITO INTERNACIONAL DOS INVESTIMENTOS: UMA MANIFESTAÇÃO DO DIREITO TRANSNACIONAL

Vivian Daniele Rocha Gabriel 
O DIREITO TRIBUTÁRIO SOB UMA PERSPECTIVA TRANSNACIONAL

Franciele de Simas Estrela Borges

As Características do Direito Transnacional como Metodologia: Análise sob o enfoQue dos Aspectos Processuais da Arbitragem 126

Flávia Foz Mange

O DIREITO TRANSNACIONAL (“GLOBAL LAW") E A CRISE DE PARADIGMA DO ESTADO-CENTRISMO: É POSSÍVEL CONCEBER UMA ORDEM JURÍDICA TRANSNACIONAL? ...................................... 146

Luiza Nogueira Barbosa e Valesca Raizer Borges Moschen

TransPorte AÉREO E DIREITO TRANSNACIONAL: DA CONVERGÊNCIA À UNIFORMIDADE 160 Mickael R. Viglino

Outros Artigos. 175

O Fundo Monetário Internacional e a proteção dos direitos humanos: uma análise DO PROGRAMA DE CRESCIMENTO E REDUÇÃO DA POBREZA NO HAITI 177

Pablo Henrique Hubner de Lanna Costa e Carlos Alberto Simões de Tomaz

Um estranho no ninho? Padrões privados no Acordo de Barreiras Técnicas ao CoMÉRCIO DA OMC 192

Michelle Ratton Sanchez Badin e Marina Yoshimi Takitani

Os benefícios tributários do programa Inovar-Auto e os princípios da Nação Mais Favorecida e do Tratamento Nacional: uma análise dos argumentos dos Painéis atualmente em Curso contra o Brasil no Órgão de SoluÇão de Controvérsias da OMC . 211 Eric Moraes Castro e Silva

A ERA DA HUMANIDADE: REFLEXões PARA A HISTÓRIA DO DIREITO INTERNACIONAL 236 Henrique Weil Afonso

Precedentes vinculantes nos Estados Unidos da América e no direito brasileiro: Um ESTUDO COMPARADO 264

Patrícia Perrone Campos Mello 
IL DIRITTO AMBIENTALE SECONDO L'OTTICA DEL DIRITTO COSTITUZIONALE POSITIVO E LA RESPONSABILITÀ PER DANNI ALL'AMBIENTE NEL DIRITTO COMUNITARIO: LO STATO DELL'ARTE DEL DIRITTO AMBIENTALE COSTITUZIONALE E COMUNITARIO 287

Elcio Nacur Rezende

DA DESCONSIDERAÇÃo DA PERSONALIDADE JURÍDICA NAS RELAÇÕES CONSUMEIRISTAS BRASILEIRAS: ANÁLISE À LUZ DAS TEORIAS CLÁSSICAS

Daniel Amin Ferraz e Marcus Vinicius Silveira de Sá

ANALYSIS OF ADVANTAGES AND DISADVANTAGES OF FORUMS PRESCRIBED UNDER THE UNCLOS AND STATE PRACTICE: THE WAY AHEAD FOR INDIA ......................................................319

Vinai Kumar Singh

Do governo POR LEIS À governanÇA POR NúMERos: breve anÁlise do Trade in SERVICE AgreEMENT (TISA) ...............................................................................338 Jânia Maria Lopes Saldanha, Rafaela da Cruz Mello e Têmis Limberger

As DIRETIVAS EUROPEIAS COMO NORMA REGULADORA DO DIREITO ADMINISTRATIVO GLOBAL ..356 Alice Rocha da Silva e Ruth Maria Pereira dos Santos

O desenVolvimento da POlítica AGRícola COMUM dA UNião EUROPEIA 375 Tatiana de A. F. R. Cardoso Squeff

A imunidade de Jurisdição das organizaÇões internacionais FaCE AO Direito de aCESSO À JUSTIÇA 391

Fernanda Araújo Kallás e Caetano

O DIREITO INTERNACIONAL ENTRE O DEVER ÉTICO E A AÇÃo POLÍ́TICA: OS FUNDAMENTOS DE UM DEVER DE COOPERAÇÃO INTERNACIONAL NA FILOSOFIA POLÍTICA DE IMMANUEL KANT .405 Ademar Junior Pozzatti

EXTENSÃo E FRAGMENTAÇÃo NO CONTEXTO DA JURISDIÇÃO PENAL INTERNACIONAL .423 Marcus Vinícius Xavier de Oliveira

A DEFINiÇÃo JURÍdiCA DA "COMUNIDADE" .444 Nitish Monebhurrun, Michelle Lucas Cardoso Balbino, Fernanda Castelo Branco Araujo, Othon Pantoja, Míara Bogo Bruno e Cândida Dettenborn Nóbrega 
Comparative Study on Chinese Local Legislation of Science and Technology ProGRESS

LI Xiaoming e LI Yihan

O CONTROLE PENAL DO TRÁFICO DE PESSOAS: CONSTRUÇÃO JURÍDICA, INTERAÇÕES ORGANIZACIONAIS E COOPERAÇÃO INTERNACIONAL

Bruno Amaral Machado e Priscilla Brito Silva Vieira

Desativismo judicial: a extradição Battisti no Supremo Tribunal Federal .505 Francisco Rezek e Israel Paulino

A decisão norte-americana do Caso Myriad: novos paradigmas para a Proteção patenTÁRIA DO CÓDIGO GENÉTICO HUMANO E BIOTECNOLOGIA 514 José Carlos Vaz e Dias e Clarisse De La Cerda 


\section{As diretivas europeias como norma reguladora do direito administrativo global*}

\section{The european directives as a standard of the regulations of the global administrative law}

\author{
Alice Rocha da Silva** \\ Ruth Maria Pereira dos Santos***
}

\section{Resumo}

O processo de internacionalização do direito, motivado pela globalização, alterou o cenário político, econômico, social e cultural, principalmente pós-guerra fria, momento em que se verificou a modificação no cenário jurídico internacional, com a proliferação de fontes normativas e instâncias de solução de litígios, repercutindo nos ordenamentos jurídicos nacionais. Percebeu-se, portanto, a fragmentação do direito em virtude da criação de sistemas autônomos, com a igualdade de competências e, ao mesmo tempo, a criação de redes de cooperação e instituições privadas, dando origem ao direito administrativo global, permitindo uma maior interação entre os diferentes sistemas e a padronização de procedimentos e instrumentos para a realização de objetivos comuns, decorrentes da integração de atores domésticos e internacionais. Nesse contexto, o direito administrativo global se desenvolve como um instrumento de regulação administrativa para a pluralidade normativa, jurisdicional e institucional. Dessa maneira, defende-se que as diretivas europeias como instrumento regulador do direito comunitário criam um regime de accountability entre os Estados-Membros, realizando um enfoque de regulação botton-up (debaixo para cima), pois se busca a participação na administração global por meio da ampliação e adaptação das ferramentas de direito administrativo nacional, garantindo a legalidade e responsabilidade dos atores nacionais. De igual modo, as diretivas europeias, em determinados momentos podem realizar regulação top-down (de cima para baixo), isto quer dizer que, em virtude do estabelecimento dos padrões decorrentes das diretivas, podem refletir no cenário internacional ou até mesmo em outros ordenamentos jurídicos nacionais alheios ao da União Europeia. A questão se corroboraCompleta-se com a análise do caso da OMC, WT/DS 408 e 409, que trata do confisco de medicamentos genéricos de origem indiana com destino ao Brasil, em virtude das regras europeias de proteção de propriedade intelectual.

Palavras-Chave: Direito Administrativo Global. Regulação Global. Diretivas europeias. 


\section{Abstract}

The process of the internationalization of Law, driven by globalization, changed the political, economic, social and cultural scene, especially post-Cold War, when it was found the change in the international legal setting, with the proliferation of normative sources and solution instances disputes, reflecting the national legal systems. However, the fragmentation of the law due to autonomous systems is perceived, with equal skills and at the same time, the creation of networks of cooperation and private institutions, giving rise to global administrative law, allowing greater interaction between the different systems and the standardization of procedures and tools for the achievement of common goals, resulting from the integration of domestic and international protagonists. In this context, the global administrative law develops as a device of administrative regulation for the normative pluralism, jurisdictional and institutional. Thus, it is endorsed that the European directives, as a regulatory instrument of community law create an accountability regime between Member-States, accomplishing a focus on bottom-up regulation, because it is required the participation in global governance through the expansion and adaptation of national administrative law instruments, ensuring the legality and responsibility of the national actors. In a similar way, European directives, at certain times can perform top-down regulation. This means that due to the establishment of standards, resulting from the directives can reflect on the international scene or even in other national legal systems outside the European Union. The question corroborates through the analysis of the WTO case, WT / DS 408 and 409, which deals with the confiscation of Indian generic medicines to Brazil, due to the European rules of intellectual property protection.

Keywords: Global administrative law. Global regulation. European directives.

\section{INTRODUÇão}

O ordenamento jurídico europeu enseja uma série de dúvidas e questionamentos sobre o seu funcionamento e amplitude no contexto global, principalmente, porque está muito distante da realidade brasileira e porque não costuma ser um objeto de estudo nas universidades do
Brasil, sendo uma das razões para a realização do presente estudo. Além disso, o caráter supranacional que o Direito Europeu possui, representado aqui pelas Diretivas Europeias que desempenham um papel integrador do Direito Comunitário, demonstra a necessidade de analisar a regulamentação jurídica europeia como fonte do Direito Administrativo Global.

Nesse sentido, o Direito Administrativo Global é o ponto de partida por se tratar de um instrumento de regulação administrativa para a pluralidade normativa, jurisdicional e institucional. Consiste ainda numa construção teórica da Escola de New York, com os principais teóricos Kingsbury, Krisch e Stewart e, na Europa, Sabino Cassese. Por essa razão se faz necessário conceituar o Direito Administrativo Global diferenciando-o do Direito Administrativo Nacional e do Direito Administrativo Internacional, bem como apresentar os órgãos regulatórios globais que se realizam por meio do diálogo/cooperação entre os atores e sujeitos internacionais, estabelecendo cinco topos de administração global: a administração internacional, por redes transnacionais e acordo de coordenação; administração dispersa; administração híbrida privada-intergovernamental e a regulação por órgãos privados. Ademais, é necessário esclarecer as fontes desse direito para então chegar às diretivas europeias.

A concretização do objeto de pesquisa somente é possível diante das mudanças ocorridas no contexto internacional que refletiram no Direito Internacional após o fim da Guerra Fria que, combinado com a globalização/mundialização, provocou o processo de internacionalização do Direito, modificando a visão clássica do Direito, fazendo surgir atores internacionais, normas, além das tradicionais, também as instâncias de solução de conflito. Isto permitiu uma expansão de temas que antes não eram tratados, ou somente tinham proteção no direito interno. As Organizações Internacionais assumiram um papel importantíssimo na construção do Direito Internacional contemporâneo, assim como, os atores internacionais, como Organizações Não Governamentais, empresas privadas, centros de pesquisas, dentre outros, passaram a participar ativamente do cenário global.

Tais alterações tornaram o Direito Internacional mais complexo devido à construção normativa, com a participação de atores estatais e não estatais. Inicialmente, com a criação de valores/direitos comuns surgidos 
com base nos Direitos Humanos, ou seja, com a universalização do Direito. Há, portanto, a proliferação de ramos do Direito que são internacionalizados a fim de atender as novas demandas surgidas com o processo de globalização.

Tal modificação representa uma quebra das fronteiras, pois permite um intercâmbio global a partir da interação entre pessoas físicas e jurídicas. Além disso, há, também, a redução da soberania estatal para promover a integração entre os direitos nacionais, sistemas regionais de integração e o Direito Internacional, com reorganização das competências. Paralelamente, a construção normativa não se restringe ao Estado nação, indo além das capacidades estatais, juntamente com novas instâncias de solução de conflito.

Nessa linha, o Direito Internacional demonstra-se fragmentado, por vezes, contraditório com a sociedade global por criar sistemas autônomos, todos com igualdade de competências que atuarão em conjunto com redes de cooperação e instituições privadas. A partir dessa perspectiva é que o Direito Administrativo global surge, haja vista possuir identidade de mecanismos disponíveis no Direito Nacional e Internacional, permitindo maior interação entre os diferentes sistemas, iniciando um processo de padronização de procedimentos e instrumentos para a realização dos objetivos comuns que decorrem da integração entre atores domésticos e internacionais e também em virtude de o Direito $\mathrm{Na}$ cional não conseguir alcançar respostas satisfatórias às questões transfronteiriças surgidas no contexto da internacionalização do Direito.

Nesse sentido, entende-se não ser necessário debruçar-se sobre a evolução do Direito Internacional, tratando detalhadamente sobre o seu processo de fragmentação até a formação do Direito Administrativo Global, sendo interessante para o desenvolvimento deste trabalho, iniciar pela regulação normativa do GAL. Isto porque a problemática da pesquisa é analisar a diretiva europeia que pode ser considerada como uma norma reguladora do Direito Administrativo Global, não como um funcionamento unicamente no contexto do Direito Europeu.

Portanto, o problema em questão é se a diretiva europeia, sendo parte do Direito derivado da União Europeia, pode ser uma fonte de Direito Administrativo Global, de modo a realizar uma regulação que vai além do espaço que compõe a União Europeia. Isto quer di- zer que a diretiva europeia, produzida pelos órgãos Europeus, o Parlamento Europeu e o Conselho da União Europeia, que tem o intuito de harmonizar e unificar o Direito e é direcionada a todos os Estados-Membros, de forma obrigatória (por implementação voluntária ou por meio do efeito direto) representaria uma norma reguladora do Direito Administrativo Global.

O assunto se torna importante, pois o tratamento dado ao Direito Administrativo Global ainda é muito recente, pautado, unicamente, na construção teórica doutrinária e, ao adotar esse posicionamento, aplica-se a teoria do GAL à prática. Isto porque se pode verificar que a diretiva europeia, muito embora seja uma norma de caráter regional, ter, em tese, amplitude somente nos limites intrabloco, seus efeitos podem ir além dos limítrofes territoriais e ter repercussões globais.

Para tanto, primeiramente, serão verificadas as diferenciações entre Direito Administrativo Global, Direito Administrativo e Direito Internacional, além de enquadrar o Parlamento Europeu e o Conselho da União Europeia como órgãos regulatórios com vocação global. Posteriormente, a sua origem normativa, que tem como base da sua justificativa jurídica o direito das gentes, será possível entender a natureza das normas que o compõem.

Desse modo, as diretivas europeias, em razão do objetivo de regular o direito comunitário, criam um regime de responsabilidade (accoutability) entre os Estados-Membros, pois há a obrigação de inseri-la no direito interno. Nesse caso, a União Europeia atua como um operador global, por garantir a coesão e o bom funcionamento da global e a proteção dos direitos por meio dos valores democráticos. Pode-se dizer que a União Europeia, por meio das diretivas, adota um enfoque de regulação "bottom-up" (debaixo para cima), posto que, busca garantir a legalidade, a responsabilidade (accountability) e a participação na administração global por meio da ampliação e adaptação das ferramentas de direito administrativo doméstico.

Por outro lado, as diretivas podem atuar como "top-down” (de cima para baixo) de construção do Direito Administrativo Global em virtude do estabelecimento de padrões internacionais e se relacionam com diversos temas que são debatidos em outros ordenamentos jurídicos, bem como, pode ter repercussões externas, afetando o direito de países terceiros, inseridos em um sistema multinível. 
Nessa linha é que se apresenta o caso discutido, inicialmente, na Organização Mundial do Comércio, referente ao confisco de medicamentos genéricos em trânsito (WT/DS 408 e 409), em que o Brasil e a Índia atuam como demandantes por conta das apreensões de medicamentos no aeroporto da Holanda, em virtude da diretiva 2004/48/CE, que vai de encontro com as normas da OMC e das normas de Direitos Humanos. Esse caso denota a repercussão de uma norma europeia, no caso a diretiva, no cenário global, ensejando a participação de diversos órgãos regulatórios globais, bem como atores públicos e privados na esfera global.

Portanto, verificou-se que, apesar de a diretiva europeia ser uma norma de caráter regional decorrente de um sistema regional de integração, contendo competência, apenas, para os países-membros, é possível ter repercussões para além do bloco econômico, isto porque a União Europeia integra a ordem global e seus órgãos atuam como reguladores globais, tanto da ordem comunitária para o direito nacional, quanto do ordenamento jurídico europeu para o global. A diretiva europeia representa, portanto, uma norma regulatória, pois tem o caráter uniformizador dos direitos nacionais com o direito europeu, fazendo surgir repercussões em direitos terceiros, como foi analisado no caso.

\section{REgULAÇÃO NORMATIVA A PARTIR DO DIREITO ADMINISTRATIVO GLOBAL}

O Direito Administrativo Global emerge com o intuito de:

Criação, implementação e controle de um conjunto de relações jurídicas por diversos atores, com diferentes níveis de cogência e hierarquia, cujos conflitos são resolvidos sem coordenação entre dezenas de tribunais e mesmo sem a ausência do Estado. ${ }^{1}$

Esta administração global cresce com a ideia de promoção de uma maior responsabilidade no processo de tomada de decisões e na proliferação de mecanismos reguladores globais, uma vez que o ordenamento jurídico nacional é incapaz de solucionar as questões transfronteiriças que surgiram após o processo de internacionalização do Direito e a multiplicação de atores e temas a serem tratados.

1 VARELLA, M. D. Internacionalização do Direito: direito internacional, globalização e complexidade. Brasília: UniCEUB, 2012. p. 635
Assim, o Direito Administrativo Global se desenvolve como um mecanismo de regulação administrativa para a pluralidade normativa, jurisdicional, institucional e de sujeitos que compõem o cenário global, de modo a encontrar instrumentos comuns para governança global. Nessa perspectiva importa analisar a regulação normativa a partir do Direito Administrativo Global, construindo o seu conceito, verificando as suas fontes e os órgãos que o integram.

\subsection{Conceitos de Direito Administrativo Global}

O Direito Administrativo Global é uma construção teórica, nascida na escola de New York, decorrente da evolução do Direito Internacional, dos efeitos da globalização no mundo jurídico, na economia, na política e na sociedade, em que se objetiva a aplicar conceitos de Direito Administrativo para a compreensão e regulação da ordem global. No entanto, importante destacar que o Direito Administrativo global não se confunde com Direito Administrativo Nacional ou Internacional, tampouco com direito global.

A ideia de um direito mundial, ou global, advém, desde o direito das gentes, em que se admitia a existência de um direito comum, aonde quer que o indivíduo estivesse. $\mathrm{Na}$ mesma linha, Kant defendia a existência de ordem político-jurídica mundial, ou seja, um Estado mundial, com base no direito originário universal do homem à liberdade 2 . Assim, Kant buscava a pacificação por meio de uma ordem mundial, que seria justa por ser uma ordem mundial jurídica, com a universalização do homem.

A filosofia kantiana descrita na "Paz Perpétua" preocupava-se em fundar uma República mundial constituída livremente por associação dos povos, em que o valor da igualdade e da liberdade estaria resguardado e em que todos os integrantes participassem da elaboração das leis, com vista a garantir a paz duradoura na sociedade. Desse modo, o republicanismo universal seria o responsável por garantir a paz perpétua, isto porque os Estados republicanos, por si só, não seriam completamente perfeitos, onde se permitiria a guerra injusta e escusada, portanto, um republicanismo de todos os Estados, com

2 MARTINS, Clélia Aparecida. Algumas considerações sobre o Estado e Direito em Kant. Revista Perspectiva Filosófica, v. 4, n. 11, p. 63-64, jan./jun. 1999. 
o respeito universal a todos os povos ${ }^{3}$, seria o essencial para garantir a paz social.

$\mathrm{Na}$ mesma linha, Otfried Höffe, Heinhard Steiger e Hans Kung, citado por Elias Grossman, afirma que existe um déficit normativo global, porém não se pode falar em uma ausência de direito, tampouco, de um poder coercitivo global, uma vez que, além da estrutura interna do Estado, há, também, o comprometimento realizado por meio de tratados, organizações internacionais, instituições reguladoras e instrumentos de resolução de conflito, ainda que inexista uma instância superior. O corpo institucional formado no contexto internacional permite uma adequação de acordo com as necessidades globais, bem como são consideradas a base para o desenvolvimento de uma comunidade internacional dinâmica e eficiente, com ampliação dos poderes e capacidades de agir das organizações internacionais ${ }^{4}$.

Muito embora a ideia de direito mundial exista há tempos, muitos dos juristas questionam a sua existência, ao contrário do que defende Sabino Cassese. Para ele há globalização do Direito, ou seja, há a institucionalização de uma governança global, ainda que não exista um governo global, a partir da globalização do direito. Tal acepção é adotada em virtude da plurissubjetividade, normatização, administração, jurisdição, legitimação e justiça no cenário global, decorrente da interrelação entre sistema global e nacional, bem como pela dissipação de princípios comuns, que são adotados em diferentes locais do globo, constituindo, assim, ordenamentos plurais ${ }^{5}$.

$\mathrm{Na}$ esteira da pluralidade do direito é que se justifica, também, a existência do direito global, posto que parte-se da pluralidade de sistemas jurídicos autônomos que interagem, sendo necessário respeitar a diversidade, permitindo a harmonia global, ou seja, um pluralismo ordenado, como propõe Delmas-Marty, que vislumbra a ordenação do múltiplo por meio da coordenação,

3 SANTOS, Leonel Ribeiro dos. Kant: da reinvenção do Republicanismo à ideia de uma "República Mundial". Cadernos de Filosofia Alemã, n. 16, p. 13-54, jul./dez. 2010. p. 37.

4 Grossmann, Elias. Paz. e República Mundial: de Kant a Höffe. Tese (Doutorado) - Faculdade de Filosofia e Ciências Humanas da Pontifícia Universidade Católica do Rio Grande do Sul, Porto Alegre, 2006. Disponível em: <http://tede.pucrs.br/tde_busca/arquivo.php?codArquivo=324>. Acesso em: 07 jul. 2015.

5 CASSESE, Sabino. Il diritto globale: giustizia e democrazia oltre lo Stato. Torino: EINAUDI, 2009. harmonização, unificação e hibridação ${ }^{6}$. Todavia não se adentrará no estudo das referidas teorias, uma vez que foge ao escopo do trabalho.

Assim, o direito global, apesar de não se confundir com o direito administrativo global, é o que dá o embasamento teórico para a construção do segundo, uma vez que, sem os efeitos da globalização no direito e, sobretudo no direito administrativo, não seria possível falar em regulação global ou governança global. Por se tratar de acepções recentes se faz necessário diferenciar também Direito Administrativo Internacional do Direito Administrativo Global.

O Direito Administrativo Internacional não se confunde com Direito Administrativo Global, uma vez que o primeiro se refere, necessariamente, ao processo de internacionalização do direito administrativo, tendo em vista o alargamento das relações do Estado e da extensão monista do Direito, sobretudo no contexto europeu. Referem-se, portanto, às relações transnacionais estabelecidas pelo Estado que afetam as relações jurídico-administrativas internas, e nesse contexto o Direito Administrativo Nacional não é capaz de amparar todas essas situações, haja vista a perda da produção de normas pelo Estado, e passa a se vincular a normas externas ${ }^{7}$. Sobretudo no contexto da União Europeia, onde se vislumbra a criação de um direito administrativo comunitário.

Nessa linha, o direito administrativo internacional, nas palavras de Prata Roque, define-se como aquele que tem o objetivo de produzir o regime jurídico aplicável às relações jurídico-administrativas transnacionais, não se restringindo a uma extensão territorial, posto que sua origem está centrada na internacionalização do objeto da norma administrativa. Portanto, o Direito Internacional Administrativo refere-se ao conjunto de normas que visam delimitar o domínio de incidência espacial de normas administrativas, independentemente da fonte normativa da qual advém ${ }^{8}$.

Pode-se dizer que o Direito Administrativo Internacional é o corpo de normas nacionais que regem os efeitos dos atos administrativos de um Estado estran-

6 DELMAS-MARTY, M. Le pluralisme ordonné et les interactions entre ensembles juridiques. 2006. Disponível em: <http://www.ieim.uqam. ca/IMG/pdf/article_Dalloz.pdf>. Acesso em: 7 jul. 2015.

7 SILVA, Suzana Tavares da. Um novo Direito Administrativo. Coimbra: Universidade de Coimbra, 2010. p. 12.

8 ROQUE, Miguel Prata. A dimensão transnacional do Direito Administrativo. Lisboa: AAFDL, 2014. p. 473-474. 
geiro em um sistema normativo do Estado. Todavia, o entendimento acerca do Direito Administrativo Global é mais extenso, pois abrangre todas as regras e procedimentos que contribuem para assegurar a accountability da administração global, e se concentra, sobretudo, nas estruturas administrativas, na transparência, nos elementos participativos, no procedimento administrativo, nos princípios de tomada de decisões razoáveis e nos mecanismos de revisão ${ }^{9}$, estimulando a busca por ferramentas adequadas para um grupo heterogêneo de regras (do formato à origem), porém com impactos similares na realidade com a qual interagem ${ }^{10}$.

Assim, o Direito Administrativo Global se funda na conceito de que a govenança global é compreendia como uma forma de administração que segue princípios de direito administrativo, que se expadiu para uma escala global, que além das funções administrativas, possui também, funções regulatórias. Com isso propõe uma aproximação das práticas divergentes, compreendendo-as como parte de um todo, a fim de inserir na esfera global procedimentos de Direito Administrativo, Nacional e Internacional, para realizar a regulação global de governança de maneira responsável ${ }^{11}$.

A partir dessa perspectiva o Direito Administrativo Global, em sentindo lato, é o direito aplicável a todas as situações que ultrapassam os limites dos Estados, mas que podem ter ou têm repercussões na vida administrativa dos mesmos Estados ou dos seus indivíduos. Assim, esse direito pode ser definido como o conjunto de princípios e regras jurídicas que tem por escopo a regulação da organização administrativa pública transnacional e da atividade administrativa dos órgãos que a compõem, bem como as pessoas públicas ou privadas que são afetadas pelas atividades transnacionais ${ }^{12}$.

9 KINGSBURY, Benedict; KRISCH, Nico; STEWART, Richard B. El surgimiento del derecho administrativo global. Revista de Derecho Público, Bogotá, n. 24, p. 16, mar. 2010

10 SANCHEZ BADIN, Michelle Ratton. The Global Administrative Law Project: a review from Brazil. October 1, 2008. Disponível em: <http://ssrn.com/abstract=1483379>. Acesso em: 21 jul. 2015.

11 KRISCH, Nico; KINGSBURY, Benedict. Introdução: governança global e direito administrativo global na ordem legal internacional. Revista de Direito Administrativo, Rio de Janeiro, v. 261, p. 13-32, set./dez. 2012

12 RODRÍGUEZ, Libardo. El derecho administrativo transnacional o global: un nuevo capitulo del derecho administrativo. Disponível em: <http://es.globallawpress.org/wp-content/uploads/derechoadministrativo-global-nuevo-cap \%c3\%8dtulo-2015.doc>. Acesso em: 8 jul. 2015.
Tal regulação se faz necessária devido ao entrelaçamento dos sistemas autônomos, posto que há uma diversidade de formas de regulação que irão compor o espaço administrativo global, que inclui mecanismos legais, princípios e práticas que afetam diretamente a responsabilidade dos órgãos administrativos globais, que encontrarão padrões adequados. Na esfera global, além dos instrumentos formais públicos e privados, há a inclusão de acordos institucionais informais, em algumas vezes não estatais, que serão responsáveis pela regulação global ${ }^{13}$.

Ademais, a governança global entendida como uma forma de administração, permite a reformulação das preocupações comuns acerca da legitimidade das instituições internacionais de forma mais específica e focada, proporcionando uma análise crítica do déficit democrático e dos mecanismos de accountability, o que permite maior interação entre as esferas públicas nacional e global. Isto porque o direito administrativo global trata com diferentes ramos do direito, que estão inseridos na administração global, e que, até então, foram tratados de forma separada ${ }^{14}$.

Além da diferenciação entre direito global e direito administrativo internacional, é necessário verificar quais são os órgãos e/ou organismos que possuem vocação global. Tal análise de faz necessária em virtude de se estabelecer mais adiante o Parlamento Europeu e o Conselho da União Europeia como um órgão de vocação global para produzir a fonte normativa do direito administrativo global, que é a diretiva, como se verá adiante.

\section{2. Órgãos regulatórios com vocação administrativa global}

O direito administrativo global tem levado o desenvolvimento da governança em uma escala multinível, expandindo o campo de atuação das organizações internacionais e dos tratados, os quais trazem funções reguladoras que deixam de ser exclusivamente nacionais e se tornam globais. As ações internacionais são combinadas com as nacionais em redes de coordenação glo-

13 KRISCH, Nico; KINGSBURY, Benedict. Introdução: governança global e direito administrativo global na ordem legal internacional. Revista de Direito Administrativo, Rio de Janeiro, v. 261, p. 13-32, set./dez. 2012. p. 18.

14 KINGSBURY, Benedict; KRISCH, Nico; STEWART, Richard B. El surgimiento del derecho administrativo global. Revista de Derecho Público, Bogotá, n. 24, p. 16, mar. 2010. 
bal, bem como decisões globais podem afetar o espaço nacional ou, diretamente, pessoas e/ou empresas ${ }^{15}$.

Pode-se definir a governança global como a formação de redes de administradores, tribunais e tribunais ad hoc. A participação nesses regimes internacionais e transgovernamentais, em redes e instituições, é necessária para permitir que os governos realizem, por meio da cooperação com outros estados, o que somente era possível dentro da esfera nacional ${ }^{16}$.

Nessa perspectiva, a Administração Pública Global é constituída por um arcabouço jurídico comum a vários Estados, com origens não tradicionais (fontes do direito internacional), possuindo mecanismos próprios de efetividade e de sanção, possibilitando a solução de problemas similares em virtude do compartilhamento de informações, por meios tecnológicos, de forma rápida e eficaz. Por conseguinte, há a criação de consensos, tanto das práticas administrativas quanto da profissionalização da administração pública e privada se tornam possíveis de forma mais rápida ${ }^{17}$.

Com base no diálogo ou da cooperação, se estabelecem os cinco tipos de administração global proposta por Kingsbury, Krisch e Stewart: a administração internacional por redes transnacionais; acordo de coordenação; administração dispersa; administração híbrida privada-intergovernamental e regulação por órgãos privados. Tais tipos de administração levam à regulação global com a construção de valores e princípios globais, como veremos a seguir.

A administração internacional é realizada pelas organizações internacionais formais, ou seja, os atores administrativos são as organizações intergovernamentais criadas ao abrigo de um tratado ou acordo executivo.O segundo tipo de administração é realizado com base no diálogo entre os funcionários reguladores nacionais que atuam coletivamente em redes transnacionais de acordos de cooperação. Pode ocorrer, sem necessariamente ter base em um tratado, ou pode ser resguardado por

15 TRIPATHI, Rajeshwar. Concept of global administrative law an overview. India Quarterly: A Journal of International Affairs, v. 67, p. 355, 2011. Disponível em: < http://iqq.sagepub.com/content/67/4/355>. Acesso em: 8 jul. 2015. p. 358.

16 SLAUGHTER, Anne-Marie. Sovereignty and Power in a Networked World Order. 40 Stan. J. Int'l L. 283. Disponível em: < https://www.law.upenn.edu/live/files/1647-slaughter-annemarie-sovereignty-and-power-in-a>. Acesso em: 21 jul. 2015. p. 312.

17 VARELLA, M. D. Internacionalização do Direito: Direito Internacional, Globalização e Complexidade. Brasília: Uniceub, 2012. p. 276. acordos que não são juridicamente vinculantes, porém, são efetivos, portanto verifica-se a ausência de estrutura no processo decisório e a cooperação acontece de maneira informal entre os reguladores estatais ${ }^{18}$.

A administração dispersa é aquela que se realiza por meio de reguladores nacionais com base em tratados, redes ou outros regimes cooperativos, uma vez que as agências domésticas atuam como parte do espaço administrativo global por meio de decisões que geram uma preocupação a nível global, como ocorre no contexto europeu, por meio da diretiva europeia, como se verá mais adiante. Essa atividade se refere à atuação da Administração Pública além do seu território. Isto significa que um Estado busca regular uma atividade que inicialmente se realiza em outro país. Todavia, a regulação dispersa também ocorre quando a administração nacional implementa um regime internacional ${ }^{19}$.

Outra forma de ocorrer a regulação global é por meio das entidades privadas e governamentais que realizam acordos intergovernamentais para determinados assuntos, ganhando maior amplitude, que se refere ao diálogo entre atores econômicos e científicos. Nesse processo há a participação de atores não governamentais e entidades públicas que, conjuntamente, vão promover padrões que adquirem efeitos quase que obrigatórios, como é o caso do Codex Alimentarius, que dá amparo para o Acordo de Medidas Sanitárias e Fitossanitárias $^{20}$, da Organização Mundial do Comércio.

Por fim, a regulação global realizada, especialmente por órgãos privados que estabelecem padrões normativos, mecanismos e instrumentos que são adotados por um grande número de países, tal como as normas ISO e SWIFT. Os atos praticados por essas instituições não são muito diferentes das espécies normativas públicas intergovernamentais de caráter não vinculante e podem ser, por vezes, mais eficazes que aquelas ${ }^{21}$.

Além de compreender os órgãos regulatórios que

18 KINGSBURY, Benedict; KRISCH, Nico; STEWART, Richard B. El surgimiento del derecho administrativo global. Revista de Derecho Público, Bogotá, n. 24, p. 11, Marzo 2010.

19 KINGSBURY, Benedict; KRISCH, Nico; STEWART, Richard B. El surgimiento del derecho administrativo global. Revista de Derecho Público, Bogotá, n. 24, p. 12, Marzo 2010.

20 KINGSBURY, Benedict; KRISCH, Nico; STEWART, Richard B. El surgimiento del derecho administrativo global. Revista de Derecho Público, Bogotá, n. 24, p. 12, Marzo 2010.

21 KINGSBURY, Benedict; KRISCH, Nico; STEWART, Richard B. El surgimiento del derecho administrativo global. Revista de Derecho Público, Bogotá, n. 24, p. 12, mar. 2010. 
tem vocação global, é necessário, também, entender a fonte do Direito Administrativo Global, que devido à sua natureza, as fontes clássicas do Direito Internacional não são suficientes para justificar as origens e a autoridade normativa imposta, uma vez que tais fontes não conseguem abarcar todas as relações que o DAG envolve, porque não conseguem justificar a origem e a autoridade das normas globais, não estando adaptadas à configuração das novas regulações, tampouco o direito interno pode oferecer respostas úteis para regular os operadores globais. Por essa razão, torna-se importante verificar o embasamento jurídico do Direito Administrativo Global.

\subsection{Fontes do direito administrativo global}

Acerca das fontes do direito administrativo global, ainda não há muito certeza sobre a sua origem, uma vez que se defende a inclusão de regras e regulamentos das organizações internacionais, as fontes clássicas do direito internacional público e os princípios gerais de direito, bem como as fontes normativas internas e as cortes nacionais, regionais e internacionais, que formam o espaço global. Além disso, se faz necessário considerar o reconhecimento recíproco dos atores envolvidos, criando uma relação de confiança para compartilhar informações e adotar as soluções ${ }^{22}$.

Por essa razão, sugere-se que se adote uma versão reinventada ou pós-moderna do direito das gentes (ius gentium), inspirado em Grotius, que enxerga no direito natural um tipo de código moral e uma fonte independente do direito que garante a justiça, superior ao direito positivo, mas tolerante à vontade estatal ${ }^{23}$. A finalidade dessa visão do direito natural é para que se possam abranger normas emergentes entre uma ampla variedade de atores com configurações diversas, o que permitiria propagar os procedimentos legislativos em outros campos do direito para além do Estado ${ }^{24}$.

22 VARELLA, M. D. Internacionalização do direito: direito internacional, globalização e complexidade. Brasília: Uniceub, 2012. p. 277.

23 HENNEBEL, Ludovic. Penser le droit administratif global. In: BORIS, Clementine. Un droit administratif global? Cahiers Internationaux - CEDIN, Naterre: Pedone, 2012. p. 78-79

24 KINGSBURY, Benedict; KRISCH, Nico; STEWART, Richard B. The emergence of global administrative law. Law and Contemporary Problems, v. 68, p. 15. Disponível em: <http://scholarship.law.duke. $\mathrm{edu} / \mathrm{cgi} /$ viewcontent.cgi?article $=1361 \&$ context $=\mathrm{lcp}>$. Acesso em: 10 jul. 2015. p. 29.
Por outro lado, o direito interno também tem influência na esfera global, isto porque também é considerado como fonte do direito administrativo global, posto que sirva de controle para a administração doméstica e para agências reguladoras nacionais, como para a aplicação do direito global ou agindo como parte da estrutura global. De igual modo, os tribunais nacionais, também, podem contribuir como mecanismos de solução de litígios, quando houver conflitos entre órgãos globais e entidades privadas. Isto contribui para garantir a accountability da administração global, em virtude de utilizar mecanismos de direito interno no $\mathrm{DAG}^{25}$.

Ademais, as fontes do direito administrativo global incluem também mecanismos legais, princípios e práticas que asseguram que os órgãos busquem padrões apropriados de transparência, de participação, de racionalidade e de legalidade, bem como fornecem a revisão efetiva das regras e decisões que os organismos tomam ${ }^{26}$. Isto revela a pluralidade de fontes normativas que vão além das fontes nacionais, devido a transnacionalidade das relações estatais.

Em verdade não se pode denominar uma única fonte para o direito administrativo global, uma vez que há associação espontânea de diversas fontes normativas, que podem estar associadas às fontes tradicionais ou que fogem às estruturas formais de exercício de poder público ${ }^{27}$. Assim, tanto as fontes tradicionais do direito internacional quanto as fontes de direito nacional, bem como a jurisprudência de tais ordenamentos, criam um padrão comum de referência, dando embasamento para a esfera global.

Desse modo, Tripathi apresenta três conceitos que devem fazer parte da base normativa do direito administrativo global: accountability intra-regime, proteção dos direitos e implementação da democracia. O primeiro refere-se à necessidade de se ter mecanismos para garantir a atividade coordenada entre os diferentes atores internacionais e nacionais de acordo com as normas do regime administrativo global, ou seja, por meio de controle

25 TRIPATHI, Rajeshwar. Concept of global administrative law an overview. India Quarterly: A Journal of International Affairs, v. 67, p. 355, 2011. Disponível em: < http://iqq.sagepub.com/content/67/4/355>. Acesso em: 8 jul. 2015. p. 365.

26 KRISCH, Nico; KINGSBURY, Benedict. Introdução: governança global e direito administrativo global na ordem legal internacional. Revista de Direito Administrativo, Rio de Janeiro, v. 261, p. 13-32, set./dez. 2012. p. 28.

27 ROQUE, Miguel Prata. A dimensão transnacional do direito administrativo. Lisboa: AAFDL, 2014. p. 882. 
dos atores a fim de garantir a legalidade. Dentro dessa perspectiva os mecanismos de direito administrativo interno podem desempenhar a função de controle ${ }^{28}$, como é o caso das diretivas europeias, que garantem a conformidade da lei nacional com as normas da União Europeia, com base em princípios comuns.

A proteção de direitos, associada à concepção de direitos individuais e à ideia de Estado de Direito, é o principal argumento para a criação de direitos comuns em uma escala global, pois o direito administrativo protegeria os direitos dos Estados, logo, garantiriam que os atores administrativos não ultrapassassem seus poderes nas relações com terceiros estados ${ }^{29}$. O exemplo disso é o direito da OMC, que é considerado um direito global com influência nos administradores internos e que evita o excesso de ingerência econômica de um país no outro, de modo a prejudicar as relações multilaterais estabelecias em seu acordo constitutivo.

Por fim, a implementação dos ideais democráticos é um dos pontos mais importantes e exigentes do direito administrativo global, posto que garantisse a adesão administrativa para os estatutos legislativos, oferecendo a transparência e a participação pública no processo de tomada de decisão. Na administração global, o DAG garantiria esses ideais, haja vista se basear em uma premissa de igualdade de tratamento, não discriminação, transparência e troca de informações, ou seja, a transposição desses valores para a escala global permite a implementação da democracia na base normativa do $\mathrm{DAG}^{30}$.

Apresentada a regulação realizada pelo direito administrativo global, a partir do seu conceito, dos seus órgãos regulatórios e a sua fonte normativa, passa-se à aplicação dessas considerações às diretivas europeias e ao Parlamento Europeu e o Conselho da União Europeia como integrantes do DAG, como fonte e órgão regulatório. Isto para realizar a análise da repercussão das diretivas europeias no cenário global.

28 TRIPATHI, Rajeshwar. Concept of global administrative law an overview. India Quarterly: A Journal of International Affairs, v. 67, p. 355, 2011. Disponível em: <http://iqq.sagepub.com/content/67/4/355>. Acesso em: 8 jul. 2015. p. 364.

29 TRIPATHI, Rajeshwar. Concept of Global Administrative Law An Overview. India Quarterly: A Journal of International Affairs, v. 67, p. 355, 2011. Disponível em: < http://iqq.sagepub. com/content/67/4/355>. Acesso em: 8 jul. 2015. p. 364.

30 TRIPATHI, Rajeshwar. Concept of Global Administrative Law An Overview. India Quarterly: A Journal of International Affairs, v. 67, p. 355, 2011. Disponível em: < http://iqq.sagepub. com/content/67/4/355>. Acesso em: 8 jul. 2015. p. 364.

\section{O CARÁTER TRANSNACIONAL DAS DIRETIVAS EUROPEIAS NO PLANO DO DIREITO ADMINISTRATIVO GLOBAL}

O cenário internacional multifacetado permite a interação entre as estruturas, atores e procedimentos nacionais e internacionais, bem como a criação de padrões normativos, a fim de realizar a regulação global, ou seja, a administração pautada em princípios, valores e normas comuns, posto que se encontre em uma escala global. Esse novo desenho do direito exige o reconhecimento de órgãos administrativos internacionais e transnacionais que interagem de formas complexas no espaço administrativo global, que está composto das relações inter-estatais e regulamentação em diferentes níveis.

Entre o Direito Europeu e o Direito Administrativo Global não é diferente. Há uma interação com base nas diretivas que podem ser tratadas como um padrão normativo do Direito Administrativo Global, em virtude do seu caráter harmonizador, aproximando direito comunitário e direito nacional. Além disso, o Parlamento e o Conselho da União Europeia exercem um papel de órgão regulatório em virtude da integração do espaço administrativo que realizam por meio das decisões que tomam a fim de implementar o direito europeu nas administrações nacionais por meio das diretivas.

\subsection{A interação entre o Direito da União Europeia e o Direito Administrativo Global: diretivas europeias como padrão normativo}

$\mathrm{Na}$ esteira do direito administrativo global, o direito da União Europeia, em especial a formação do direito administrativo europeu, traz uma fonte de estudo valiosa, tendo em vista o desenvolvimento e a consolidação desse direito, sobretudo com influência no cenário interno. Pela primeira vez, é desenvolvido um corpo de princípios e regras destinadas a coordenar a ação dos poderes públicos da UE e ação das administrações nacionais, de modo a coordenar a Administração Pública nacional com a Europeia, com variedade de mecanismos de integração e composição das organizações e atividades nacionais e comunitárias, ambos responsáveis pela execução administrativa das normas e políticas da $\mathrm{UE}^{31}$.

31 CHITI, Edoardo; MATTARELLA, Bernardo Giorgio. Intro- 
A relação que se forma entre o direito da UE e os direitos nacionais dos Estados membros forma um direito administrativo que funciona como controle do poder público, uma vez que há uma série de princípios comuns que são formados para dar base a este direito, tais como, transparência, acesso à informação, participação, direito de acesso a um tribunal independente, devido processo legal, direito às decisões razoáveis e bem fundamentadas. Os sistemas jurídicos europeus acrescentam proporcionalidade e confiança a esses valores comuns, o que exige uma vinculação das normas materiais e processuais ${ }^{32}$.

A relação que se forma no contexto da União Europeia que, por sua natureza, é um sistema de integração regional, é de cessão de parte de suas competências constitucionais internas a determinados órgãos a nível comunitário, que são obrigatórios nos ordenamentos jurídicos internos dos Estados membros, o que afeta as autoridades públicas e os cidadãos. Esse direito que se forma é construído com base na relação de cooperação, que afetará as relações jurídicas de um Estado, bem como, as situações entre diversos Estados ou habitantes dos diferentes Estados.

O direito administrativo europeu é resultado da influência do direito comunitário no direito administrativo nacional dos Estados-membros, impondo modificações neste. Isto quer dizer que o direito comunitário influencia diretamente o direito interno dos Estados-membros, de modo a coordenar as suas normas nacionais com o direito da UE, respeitando o Princípio do primado do direito europeu. Isto representa uma "constante interação recíproca entre dois ordenamentos jurídicos e isto gera uma coerência global na dogmática dos dois sistemas ${ }^{33} "$

Nessa linha o Princípio do Primado da União Europeia desempenha um papel fundamental frente ao direito administrativo global, haja vista ser um princípio comum e obrigatório a todos os Estados-membros, sur-

duction: The Relationships Between Global Administrative Law and UE Administrative Law. In: CHITI, Edoardo; MATTARELLA, Bernardo Giorgio (Ed.). Global Administrative Law and EU Administrative Law: Relationships, Legal Issues and Comparison. Berlin: Springer-Verlag Berlin Heidelberg, 2011. p. 8

32 WESSEL, Ramses A.; WOUTERS, Jan. The phenomenon of multilevel regulation: interactions between global, EU and national regulatory spheres. Disponível em: <http://www.utwente.nl/bms/pa/ research/wessel/wessel44.pdf>. Acesso em: 10 dez. 2015.

33 QUADROS, Fausto. A nova dimensão do direito administrativo. Coimbra: Almedina, 2001. p. 12-26. gidos de um entendimento comum formado pelos juízes do Tribunal de Justiça Europeu. É entendido como uma "exigência existencial" do direito europeu, com natureza uniformizadora, estabelecendo a hierarquia entre o direito da União com as demais ordens nacionais ${ }^{34}$. Assim, o princípio do primado atua como um regulador do direito da União Europeia com o ordenamento jurídico interno, que deve interpretar e aplicar de maneira comum o direito europeu.

Verifica-se que o princípio do primado do direito europeu, ainda que não venha disposto em nenhuma norma comunitária, atua como um valor comum hierarquicamente superior aos direitos nacionais, sendo absoluto, com força vinculante e nenhum direito nacional (entende-se todos os atos nacionais proferidos pelos poderes legislativo, executivo e judiciário) contrário às normas comunitárias, inclusive constitucionais, terá validade, devendo ser suspensa do ordenamento jurídico interno, até a sua conformação com o direito europeu.

A importância do princípio do primado para o direito administrativo global reside na atuação daquele para assegurar a accountability (responsabilidade/prestação de contas) da administração global por meio das estruturas administrativas europeias e nacionais. Haja vista que os princípios de direito administrativo, qual o princípio do primado se enquadra, desempenham um papel importante na jurisprudência comunitária, pois se tornam fonte do direito comunitário ${ }^{35}$, refletindo, diretamente, na esfera global, que tem a preocupação no funcionamento dos princípios existentes, das regras procedimentais, dos mecanismos de revisão e outros mecanismos relativos à transparência, participação, razoabilidade nas decisões e a garantia da legalidade da governança global ${ }^{36}$.

Resta estabelecer que o primado do direito da União Europeia é imprescindível para garantir a aplicação do direito europeu, bem como dever ser compreendido como absoluto, ou seja, "todo o Direito da União prevalece sobre todo o Direito estadual. Isto quer dizer que

34 QUADROS, Fausto. Direito da União Europeia. Coimbra: Almedina, 2015. p. 512.

35 QUADROS, Fausto. A nova dimensão do direito administrativo. Coimbra: Almedina, 2001. p. 27.

36 KINGSBURY, Benedict; KRISCH, Nico; STEWART, Richard B. The emergence of global administrative law. Law and Contemporary Problems, v. 68, p. 15. Disponível em: <http://scholarship.law.duke. $\mathrm{edu} / \mathrm{cgi} /$ viewcontent.cgi? article $=1361 \&$ context $=\mathrm{lcp}>$. Acesso em: 10 jul. 2015. p. 351. 
ele envolve todas as suas fontes que obrigam: portanto, para além do Direito originário, os regulamentos, as diretivas, as decisões, os acordos internacionais concluídos pela Comunidade ${ }^{37 \%}$.

Com base no princípio do primado do direito europeu, é possível verificar a espécie de regulação global que se refere à administração por meio de reguladores nacionais abarcados por tratados, redes ou outros regimes de cooperação. Nesse caso a regulação se realiza em virtude do tratado de constituição da União Europeia, estabelecendo padrões normativos, de ordem comunitária, que devem ser implementados nos ordenamentos internos, que também podem ter repercussões para além do bloco regional.

Nessa linha, a diretiva europeia, entendida como direito derivado e prevista no artigo 288 do Tratado de Funcionamento da UE (TFUE), pode representar uma fonte de direito administrativo global, como será visto adiante. Haja vista, pois esse mecanismo de direito regional, aplicável em âmbito nacional e com repercussões internacionais, tem o caráter uniformizador de cooperação, a fim de harmonização das ordens jurídicas nacionais com o direito da União Europeia. Assim, nota-se um regime de cooperação entre as ordens nacionais e o direito europeu, que se realiza por meio do Conselho da União Europeia, entendido aqui, como órgão regulatório de direito administrativo global.

\subsection{A regulação global por meio do Parlamento Europeu e do Conselho da União Europeia}

A contextualização do direito administrativo global pressupõe a existência de uma administração global ou transnacional, como é o caso europeu, que envolve as esferas nacionais e a esfera comunitária, a fim de coordenar e dar assistência às administrações domésticas dos Estados-membros. Isto decorre da formação do espaço administrativo multifacetado, constituído por vários e diversos tipos de instituições regulatórias administrativas e de vários tipos de entidades que são sujeitos da regulação, incluindo os Estados, indivíduos, empresas e ONGs.

O Conselho da União Europeia e o Parlamento Europeu realizam uma administração dispersa como já explicado anteriormente, pois há decisões que geram

37 QUADROS, Fausto. Direito da União Europeia. Coimbra: Almedina, 2015. p. 517. preocupação em nível internacional ou global, integrando parte do espaço administrativo global. Por outro lado, a administração doméstica dos Estados-membros se encarregam de implementar o regime transnacional/ comunitário, que ocorre por meio da harmonização da ordem jurídica da União com as ordens nacionais, a fim de estabelecer um direito comum, que tem seguido uma progressão, no sentido da "europeização dos direitos estaduais $^{38 "}$.

As medidas de harmonização são de competência da União, devendo ser aprovadas pelo Parlamento Europeu e pelo Conselho da União Europeia, conjuntamente, representam o principal órgão decisório da União Europeia. Por um lado, o Parlamento Europeu, com a escolha dos seus representantes por meio de eleições diretas, para exercer as responsabilidades legislativas, orçamentárias e supervisionar as políticas nacionais, a fim de exercer o controle democrático das instituições. De outro lado, o Conselho da União Europeia tem a competência para aprovar e coordenar as políticas comunitárias.

O Parlamento Europeu e o Conselho da União Europeia atuam como órgãos regulatórios transnacionais, posto que suas decisões têm efeitos no âmbito interno e internacional, compondo os mecanismos de accountability administrativa interna. Tais órgãos visam à proteção dos direitos privados ou dos Estados, por meio da coordenação do direito comunitário com os direitos nacionais e à proteção da democracia por meio do controle democrático.

A administração interna exercida pelos dois órgãos europeus para a realização da accoutability se concentra em três pontos fundamentais: assegurar a responsabilidade dos atores do regime administrativo, a proteção dos direitos individuais e a promoção da democracia. $\mathrm{O}$ primeiro se refere à proteção da legalidade administrativa por meio das funções organizacionais e políticas, via legislativo e executivo, bem como, visa à integridade do regime administrativo ${ }^{39}$, que ocorre na União Europeia pelo exercício das competências do Parlamento Europeu e do Conselho da União Europeia, principalmente

38 QUADROS, Fausto. Direito da União Europeia. Coimbra: Almedina, 2015. p. 306-308.

39 KINGSBURY, Benedict; KRISCH, Nico; STEWART, Richard B. The emergence of global administrative law. Law and Contemporary Problems, v. 68, p. 15. Disponível em: < http://scholarship.law.duke. $\mathrm{edu} / \mathrm{cgi} / \mathrm{viewcontent}$.cgi?article $=1361 \&$ context $=\mathrm{lcp}>$. Acesso em: 10 jul. 2015. p. 23 
quando realizam a política de coordenação, em especial, por meio das diretivas.

O segundo objetivo do direito administrativo global que se realiza por meio da administração interna é a proteção dos direitos individuais e dos demais atores que compõem a sociedade civil. Desse modo, as ferramentas de direito administrativo europeu e nacional protegeriam o direito do Estado, assegurando que os agentes administrativos não ultrapassem suas capacidades em relação a outros Estados-membros, bem como de outros países que estão fora do contexto da União Europeia, caso que será analisado posteriormente.

Por fim, a promoção e implementação da democracia, que se realizará por meio do direito administrativo doméstico, o qual garantiria o respeito à observância do princípio da transparência e da participação pública na regulação administrativa ${ }^{40}$. $\mathrm{O}$ alcance dos ideais democráticos decorrerá da participação do indivíduo na esfera pública e isto somente seria possível na esfera global com base em políticas coordenadas ou por cooperação, o que já ocorre entre a União Europeia e os Estados-membros que acolhem direitos comuns em seus ordenamentos jurídicos, válidos, de maneira igual a todos os cidadãos europeus, bem como da prestação de contas de forma equânime para todos os membros do bloco.

Portanto, o Parlamento Europeu e o Conselho da União Europeia, ao aprovarem medidas de harmonização, garantem um nível mínimo de proteção aos direitos individuais, bem como, a proteção de direitos coletivos como saúde, segurança, meio ambiente, defesa dos consumidores e outros. Essa harmonização se realiza por meio das diretivas, que têm por objetivo a "aproximação das disposições legislativas regulamentares e administrativas dos Estados-membros que tenham incidência direta no estabelecimento ou no funcionamento do mercado interno", conforme disposto no art. 115, TFUE.

Devido a essa característica harmonizadora que as diretivas possuem é que se propõe neste trabalho a sua ligação com o direito administrativo global, como fonte normativa deste. Por um lado, a diretiva tem repercussões intrabloco, ou seja, somente para aqueles países que estão inseridos na União Europeia. De outro lado, a

40 KINGSBURY, Benedict; KRISCH, Nico; STEWART, Richard B. The emergence of global administrative law. Law and Contemporary Problems, v. 68, p. 15. Disponível em: <http://scholarship.law.duke. $\mathrm{edu} / \mathrm{cgi} /$ viewcontent.cgi? article $=1361 \&$ context $=\mathrm{lcp}>$. Acesso em: 10 jul. 2015. p. 24 diretiva pode ter repercussões no direito de outros países, uma vez que estabelece padrões globais, como se verá a análise dos casos.

\subsection{As diretivas europeias como fonte normativa do direito administrativo global}

No direito administrativo global, não há nenhuma regra específica para o seu reconhecimento, pois as fontes desse direito ainda são contraditórias, pairando na ideia de um direito das gentes reinventado, como visto anteriormente. A proposta é considerar que tanto a força normativa, quanto a validade, independe da natureza daquele (órgão) que a define, mas em função das suas qualidades próprias. Assim, uma norma pode ser considerada como de DAG pelo simples fato de atender os requisitos de publicidade, intrínseco ao direto público, visando ao bem comum e ao serviço público, devendo, também, respeitar os princípios administrativos, o Estado de Direito e o direito dos homens ${ }^{41}$.

A diretiva, como direito derivado da União Europeia, tem como objetivo regular o direito comunitário, a fim de criar um regime de responsabilidade (accoutability) entre os Estados-Membros, que devem incorporá-la no seu direito interno, a fim de respeitar, tanto as funções, como as regras internas da União Europeia, que, nesse caso, figura como operador global. É por meio da diretiva aplicada voluntariamente ou por meio do efeito direto que se garante a coesão, o bom funcionamento dessa administração global e a proteção dos direitos por meio dos valores democráticos.

Vale lembrar que a diretiva comunitária, como os outros regulamentos normativos europeus, têm prevalência de aplicação em relação à legislação estatal, no que se refere ao direito comunitário ${ }^{42}$, portanto, os Estados-membros são obrigados a interpretar o seu direito com base na diretiva e excluindo disposições contrárias. A diretiva tem o caráter de vincular os seus destinatários, devendo ser aplicada na integralidade, após a transposição para o direito interno, que fica a cargo do país, a melhor forma de incorporar a diretiva ao seu ordenamento jurídico interno.

41 HENNEBEL, Ludovic. Penser le droit administratif global. In: BORIS, Clementine. Un droit administratif global? Cahiers Internationaux - CEDIN, Naterre: Pedone, 2012. p. 78-79.

42 CANOTILHO, J.J. Gomes. Direito Constitucional e teoria da constituição. Coimbra: Almedina, 2015. p. 825. 
Assim, no momento da entrada em vigor da diretiva no ordenamento jurídico da União, torna-se obrigatório aos Estados a admissão de medidas internas necessárias para o cumprimento integral das obrigações decorrentes da diretiva, bem como divulgar os direitos que elas conferem aos particulares e eliminar normas divergentes. A partir desse momento, os Estados não devem praticar atos contrários ao determinado na normativa europeia, sob pena de responsabilização civil e extracontratual do Estado ${ }^{43}$.

Desse modo, o Estado-membro tem a obrigação de transpor a diretiva para o ordenamento jurídico dentro do prazo determinado e de forma legítima. Isto quer dizer que a diretiva deve acatar as ordens internas de uma mesma maneira dentro do mesmo prazo, respeitando as diferenças legislativas de cada país. O direito europeu decorrente dessa norma passa a ser o mesmo para todos os membros da União Europeia, o que representa regulação do direito da União por meio dos direitos nacionais em prol da legitimidade da estrutura global, pois há a conciliação entre administração nacional e administração regional representada pelo Parlamento Europeu e pelo Conselho da União Europeia, com repercussões na esfera global.

Importa destacar que, para manter a uniformidade das ordens jurídicas nacionais com a União, o direito europeu impõe a sanção do efeito direto, com base no art. 4, n. 3 e 288, do TFUE, que impõe o caráter obrigatório para a diretiva. A diretiva tem efeito direto quando as suas disposições são incondicionais, devem ser claras e precisas e encontrar intempestivas, esse efeito se dá por via vertical, ou seja, pode ser invocado perante a Administração Pública ou Poder Judiciário.

O princípio do efeito direto, em conjunto com o princípio do primado, afiança os particulares de se socorrerem da norma europeia junto a uma jurisdição nacional ou europeia, além de garantir a aplicabilidade e eficácia do direito europeu nos ordenamentos jurídicos internos. Posto isto, o entendimento do efeito direto permeia três noções essenciais. A primeira se refere à obrigação dos Estados-membros de aplicar direta ou imediatamente a norma europeia em suas ordens jurídicas nacionais. A segunda é o reconhecimento dos direitos subjetivos aos particulares, podendo ser requeridos no judiciário nacional. Por fim, a obrigação dada

43 QUADROS, Fausto. Direito da União Europeia. Coimbra: Almedina, 2015. p. 475. à jurisdição nacional de garantir o exercício dos direitos dos indivíduos.

Com isto, se deduz que o princípio do efeito direto é a manifestação da garantia constitucional de aplicação imediata dos direitos traduzida no direito comunitário, de modo a proporcionar ao titular de direitos o seu exercício, independentemente se há legislação interna que concretize aquele direito ou disposição contrária ${ }^{44}$.

Nessa toada, percebe-se que a diretiva tem tomado um caráter de regulamentador, por meio do juiz europeu responsável por assegurar a plena eficácia dessa norma no ordenamento jurídico interno, bem como conferir direitos que não foram salvaguardados pela legislação nacional ${ }^{45}$. $\mathrm{O}$ objetivo da diretiva não é mais, simplesmente de harmonização, mas também instrumento de regulação, entendida como um mecanismo de intervenção limitada, posto que visa restringir e direcionar o comportamento dos Estados-membros de acordo com as normas estabelecidas por um órgão hierarquicamente superior ${ }^{46}$.

Esse caráter assumido pelas diretivas em face dos direitos nacionais adota um enfoque denominado "bottom-up", ou seja, debaixo para cima, que procura assegurar a legalidade, a responsabilidade (accountability) e a participação na administração global por meio da ampliação e adaptação das ferramentas de direito administrativo doméstico. Isso ocorre quando as instituições de governança transnacionais como a União Europeia, assumem o controle de antigas funções administrativas nacionais que estavam sujeitas a mecanismos de direito administrativo interno de transparência, participação e revisão, porém, não eram exigidos.

Nesse passo, a Administração Pública doméstica, em virtude da sua própria natureza jurídica, é incapaz de gerir sozinha a nova estrutura composta pelo direito europeu. Por esta razão os órgãos regulatórios europeus, Parlamento e Conselho, assumem o papel de

44 DUARTE, Maria Luísa. União Europeia e Direitos Fundamentais: no espaço da internormatividade. Lisboa: AAFDL, 2013. p. 346348.

45 VILAÇA, José Luís. A propósito dos efeitos das directivas na ordem jurídica dos Estados-membros. Justiça Administrativa, n. 30, nov./dez. 2001. Disponível em: <www.fd.unl.pt/docentes_docs/ ma/np_MA_15752.pdf>. Acesso em: 15 jul. 2015.

46 VILAÇA, José Luís. Directivas Comunitárias. 2010/2011. Elaborado por MAN TENG IONG. Disponível em: < http://www. fd.unl.pt/docentes_docs/ma/jlcv_MA_12764.pdf > . Acesso em: 15 jul. 2015. 
revisar a ação administrativa doméstica, que tem por dever implementar as decisões internacionais - e aqui entenda-se a diretiva também. Por outro lado, há, também, a participação dos administradores domésticos no processo de tomada de decisão que se verifica pela participação dos países no Conselho e a representação do cidadão europeu por meio do Parlamento ${ }^{47}$.

Além disso, o Poder Judiciário assume um papel importante, pois há ampliação do poder de revisão das cortes domésticas para incluir as decisões internacionais que afetam diretamente os indivíduos, com a possibilidade de afastar o direito nacional se infringir os padrões normativos estabelecidos em nível global ${ }^{48}$. Tal situação se concretiza com base no efeito direto, uma vez que o juiz é chamado a aplicar o direito decorrente da diretiva, que não foi transposta ou ocorreu a transposição de forma indevida, nesse caso é de competência do juiz nacional aplicar o efeito direto à diretiva, garantindo os direitos daí decorrentes.

De igual modo, o Direito da União Europeia também atua em uma abordagem "top-down" (de cima para baixo) de construção do direito administrativo global ${ }^{49}$. Isso porque estabelece padrões contemporâneos, que podem ser denominados como internacionais, e se relacionam com diversos temas que são debatidos em outros ordenamentos jurídicos, bem como, pode ter repercussões externas, afetando o direito de países terceiros, inseridos em um sistema multinível, que será o foco do tópico seguinte.

\section{A influênCia das diRetivas EUROpeIAS No DIREITO ADMINISTRATIVO GLOBAL: CONFISCO DE MEDICAMENTOS GENÉRICOS VERSUS O RESPEITO DOS DIREITOS DE PROPRIEDADE INTELECTUAL}

O direito da União Europeia tem uma relação direta com o direito administrativo global, ainda pouco pes-

47 KINGSBURY, Benedict; KRISCH, Nico; STEWART, Richard B. Anexxe: l'emergence du droit administratif global. In: BORIS, Clementine. Un droit administratif global? Cahiers Internationaux CEDIN, Naterre: Pedone, 2012. p. 348.

48 KINGSBURY, Benedict; KRISCH, Nico; STEWART, Richard B. Anexxe: l'emergence du droit administratif global. In: BORIS, Clementine. Un droit administratif global? Cahiers Internationaux CEDIN, Naterre: Pedone, 2012. p. 355.

49 KINGSBURY, Benedict; KRISCH, Nico; STEWART, Richard B. Anexxe: l'emergence du droit administratif global. In: BORIS, Clementine. Un droit administratif global? Cahiers Internationaux CEDIN, Naterre: Pedone, 2012. p. 357. quisado, com literatura escassa e observado por meio do diálogo judicial. No entanto, o direito administrativo europeu é considerado como um sistema de regulação global, como fora demonstrado anteriormente. Além disso, o direito oriundo das diretivas europeias pode funcionar de modo horizontal, ou seja, entre diferentes sistemas regulatórios globais, pois a diretiva ao traçar um padrão normativo para a União Europeia reflete um entendimento único dentro de um espaço jurídico global, que interagirá com outros sistemas normativos globais, tais como a ONU, a OMC, o FMI, o Banco Mundial e outros.

De um lado, o direito europeu e os regulamentos globais podem, por vezes, ser semelhantes, convergirem e se reforçarem mutuamente, como por exemplo, nos direitos humanos, na proteção do meio ambiente e padrões técnicos. De outra via, pode existir o conflito entre os instrumentos administrativos da União Europeia com outros de natureza também global, pois podem funcionar de forma equivalente. Por fim, a interação entre a UE e o direito administrativo global pode dar origem a uma concorrência normativa, ocorrer a não cooperação, e, sobretudo, o conflito entre os dois conjuntos de leis administrativas ${ }^{50}$.

A análise dos casos será pautada no conflito entre as leis administrativas globais da União Europeia, em especial as diretivas, em virtude de seu caráter harmonizador e regulatório, conforme demonstrado outrora, e o direito da OMC. A proposta é verificar que a diretiva europeia é uma fonte normativa do direito administrativo global, posto que, apesar de ter vigência apenas para os Estados-membros, o estabelecimento de padrões comuns no território europeu, tem repercussões no ordenamento jurídico de países terceiros, que buscarão a normativa global da OMC para solucionar a divergência, posto que a administração nacional de outro país não pode invadir a esfera do outro, devendo utilizar da regulação global realizada pelo Órgão de Solução de Conflitos da OMC.

Será analisado o caso oriundo da OMC, referente aos processos WT/DS 408 e $409^{51}$, confisco de medica-

50 CHITI, Edoardo. GAL and EU administrative law: A research agenda. In: CASSESE, Sabino et. al. (Org). Global Administrative Law: An Italian Perspective. 2012. p. 81-86. Disponível em: < http://cadmus.eui.eu/bitstream/handle/1814/22374/RSCAS_PP_2012_04. pdf? sequence $=1 \&$ is Allowed $=\mathrm{y}>$. Acesso em: 07 dez. 2016. p. 85 . 51 Para fins didáticos utilizará somente o caso WT/DS 409, pois ambos os casos têm reclamações idênticas. 
mentos genéricos em trânsito, em que a União Europeia e a Holanda são demandadas pelo Brasil e pela Índia, motivada pela diretiva 2004/48/CE. O caso denota a relação entre os regulamentos da União Europeia, e no caso do presente trabalho, importa destacar a diretiva e o direito da OMC com a repercussão em direito de terceiros.

A controvérsia iniciou, oficialmente, em maio de 2010. O Brasil e a Índia ingressaram com o pedido de consultas - primeira fase do processo na OMC com a União Europeia e a Holanda em virtude das diversas apreensões de medicamentos genéricos originários da Índia. Principalmente em 2008, após a retenção de $570 \mathrm{~kg}$ de Losartan de Potássio, medicamente destinado ao tratamento de pressão arterial, no aeroporto de Schiphol, que estava em trânsito na Índia, com destino ao Brasil. Salientou-se que, por diversas vezes, o medicamento foi confiscado (de 19 envios, 16 foram apreendidos), representando um montante considerável da mercadoria que era destruída ou devolvida para o país de origem.

As partes demandantes argumentaram que as retenções eram injustificáveis, pois descumpria o previsto no Acordo sobre os aspectos dos direitos de propriedade intelectual relacionados ao comércio (ADPIC/TRIPS), uma vez que a inexistência de patentes do fármaco no Brasil e na Índia, não autorizava a Holanda confiscar o medicamento em vista da proteção patentária em seu país. Desse modo, a Índia entendeu que os confiscos foram feitos com base na "fabricação de ficção", que significa dizer que o medicamento estava sendo tratado como se tivesse sido fabricado na Holanda, ${ }^{52}$ pois os detentores da patente do Losartan eram as multinacionais Merck Sharp e Dohme (MSD) e Du Pont, por isso a lei nacional, como a lei comunitária permitia a medida.

Pautado pela Lei Europeia, em destaque a Diretiva 2004/48/CE (pois uniformiza o direito europeu com o direito nacional), em seu art. $9^{\circ}$, determina que os Estados-Membros, em seu ordenamento jurídico interno, devem estabelecer medidas provisórias e cautelares para garantir que as autoridades judiciais nacionais competentes decretem contra o suposto infrator uma "medida inibitória de qualquer violação iminente de direitos

52 WORLD TRADE ORGANIZATION. European Union and a Member State: Seizure of Generic Drugs in Transit (WT/DS 409). 2010. Disponível em: <https://www.wto.org/english/tratop_e/ dispu_e/cases_e/ds409_e.htm>. Acesso em: 10 jul. 2015. de propriedade intelectual ${ }^{53}$ ", bem como "ordenar a apreensão ou a entrega dos bens que se suspeite violarem direitos de propriedade intelectual, a fim de impedir a sua entrada ou circulação nos circuitos comerciais ${ }^{54}$ ".

No entanto, a diretiva europeia encontrava-se, de certo modo, em confronto com a disposição da OMC, ou seja, duas normas de caráter global que estabeleceram direitos e deveres divergentes. Isto porque o acordo TRIPS permite que um determinado medicamento possa ser protegido por meio de patente em um país, porém em outro não. Tal permissivo jurídico admite essa situação quando: a) não houve o pedido de depósito no país; b) o prazo da patente expirou (caiu em domínio público); c) por rejeição do pedido de patente que não atendeu os critérios nacionais de patenteabilidade; e d) o invento não era objeto de patente no ordenamento jurídico nacional. Além disso, o art. V, do GATT', determina que deva existir a liberdade de trânsito de modo que os países-membros não impeçam o comércio internacional por meio de barreiras ${ }^{55}$.

Ademais, a controvérsia demandou também a denúncia no Tribunal Permanente dos Povos (TPP), em maio de 2010 - em concorrência com a demanda na OMC, por meio das organizações da sociedade civil dos países afetados pelas apreensões, como o Brasil, Colômbia, Peru e Equador. O TPP é um tribunal de opinião, sem vinculação governamental, que surgiu no contexto dos crimes contra a humanidade que foram praticados pelos EUA na guerra contra o Vietnã, sendo, formalmente, constituído na Itália, em 1979. O tribunal é ad hoc e tem a competência para julgar as violações de direitos por Estados e atores internacionais (instituições mone-

53 a) Decretar contra o infrator presumível uma medida inibitória de qualquer violação iminente de direitos de propriedade intelectual ou de proibição, a título provisório e eventualmente sujeita a quaisquer sanções pecuniárias compulsivas previstas na legislação nacional, da continuação da alegada violação dos referidos direitos, ou fazer depender essa continuação da constituição de garantias destinadas a assegurar a indenização do titular; pode igualmente ser decretada uma medida inibitória, nas mesmas condições, contra qualquer intermediário cujos serviços estejam a ser utilizados por um terceiro para violar direito de propriedade intelectual; as medidas inibitórias contra intermediários cujos serviços estejam a ser utilizados por terceiros para violar direitos de autor ou direitos conexos são abrangidas pela Diretiva 2001/29/CE;

54 Diretiva 2004/48/CE.

55 WORLD TRADE ORGANIZATION. Trade-Related Aspects of Intellectual Property Rights (TRIPS). Disponível em: < https:// www.wto.org/english/docs_e/legal_e/27-trips_01_e.htm>. Acesso em: 15 jul. 2015. 
tárias e empresas transnacionais) ${ }^{56}$.

A denúncia teve o intuito de apresentar os crimes realizados pelas empresas transnacionais detentoras das patentes e os impactos decorrentes das apreensões sobre os direitos econômicos, sociais e culturais das sociedades latino-americanas e caribenhas, bem como, por violação aos direitos humanos (saúde e vida) em virtude das barreiras à entrada dos medicamentos nos países em questão ${ }^{57}$.

Apesar da decisão do TPP não ter caráter de cogência, porém representa um órgão regulatório com vocação global, denotando grande repercussão da sociedade internacional, pois os peritos e os jurados consideraram inaceitável que as políticas patentárias da UE dificultavam o acesso aos medicamentos genéricos, e solicitaram que as retenções fossem interrompidas, recomendando que a UE reconhecesse a necessidade fundamental do uso de medicamento para as populações menos providas, pois o uso do medicamento é considerado como recurso básico para uma vida digna e sua privação poderia ser qualificada como crime contra a humanidade ${ }^{58}$.

Importa destacar que a Europa praticava reiteradamente o confisco de medicamentos, na mesma situação do Losartan, como medicamentos para AIDS, tuberculose, malária, antibióticos e para colesterol, ferindo o direito humano ao acesso a medicamentos, bem como impedindo os direitos econômicos decorrentes do Acordo TRIPS.

Os desdobramentos do caso corroboram para a construção do direito administrativo global, isto porque a controvérsia parte das normas europeias, que permite o confisco de medicamentos genéricos com base na proteção da patente no referido território. Todavia, a repercussão do direito europeu não se restringiu, apenas, aos Estados-membros, violou não somente o di-

56 ENLAZANDO ALTERNATIVA. Empresas transnacionais europeias na América Latina: estudo de caso de transnacionais farmacêuticas no Brasil. 2008. Disponível em: <http://www.enlazandoalternativas.org/IMG/pdf/5-POR.pdf>. Acesso em: 15 jul. 2015.

57 ICTSD. Apreensões de medicamentos genéricos e a condenação da UE no Tribunal Permanente dos Povos. 2010. Disponível em: < http:/ /www. ictsd.org/bridges-news/pontes/news/apreens $\% \mathrm{C} 3 \%$ B 5 es-de-medicamentos-gen $\% \mathrm{C} 3 \% \mathrm{~A} 9$ ricos-e-a-condena $\% \mathrm{C} 3 \% \mathrm{~A} 7 \% \mathrm{C} 3 \% \mathrm{~A} 3 \mathrm{O}-$ da-ue-no-tribunal>. Acesso em: 14 jul. 2015.

58 ICTSD. Apreensões de medicamentos genéricos e a condenação da UE no Tribunal Permanente dos Povos. 2010. Disponível em: <http://www. ictsd.org/bridges-news/pontes/news/apreens $\% \mathrm{C} 3 \% \mathrm{~B} 5 \mathrm{es}$-de-medicamentos-gen $\% \mathrm{C} 3 \% \mathrm{~A} 9$ ricos-e-a-condena $\% \mathrm{C} 3 \% \mathrm{~A} 7 \% \mathrm{C} 3 \% \mathrm{~A} 3 \mathrm{O}-$ da-ue-no-tribunal>. Acesso em: 14 jul. 2015. reito dos países junto à $\mathrm{OMC}$, mas também, dos indivíduos de acesso a medicamentos. Ademais, envolveu diversos entes regulatórios de natureza e estatal e não estatal, posto que as $\mathrm{ONGs}^{59}$ europeias, latino-americanas e caribenhas desempenharam um papel crucial, juntamente com o Grupo de Trabalho sobre Propriedade Intelectual da Rede Brasileira Pela Integração dos Povos $(\text { REBRIP })^{60}$, que levou à denúncia ao TPP.

\section{Considerações finais}

No trabalho desincumbiu-se de verificar se as diretivas europeias, enquanto norma harmonizadora do direito derivado da União Europeia, pode representar uma fonte, ou seja, norma reguladora do direito administrativo global. Tal questionamento se torna objeto de investigação, pois a norma produzida pelos órgãos europeus, Conselho e Parlamento Europeu, e direcionada aos Estados-Membros, no contexto intrabloco, com o objetivo de uniformizar o Direito Europeu com os direitos nacionais pode, em determinados casos, exceder os limites comunitários repercutindo no cenário global.

Para isso, tratou-se a existência da regulação normativa por meio do DAG, apresentando o conceito, uma vez que o entendimento sobre o tema ainda perpassa por uma construção teórica, discutindo-se, inclusive, a fonte normativa ou a origem dessa modalidade de organização administrativa global. Além disso, demonstrou a forma de regulação global a partir dos órgãos regulatórios, que trazem consigo a característica global, adequando o Parlamento e o Conselho da União Europeia nesta qualidade.

59 IFARMA (Colômbia), Fundación Misión Salud (Colômbia), Mesa de ONGs que trabajan con VIH/Sida (Colômbia), Red Colombiana de Personas viviendo con VIH/Sida (Colômbia), Acción International para la Salud - Latino America y Caribe (Peru) e Coalición Ecuatoriana de Personas Viviendo Con VIH/SIDA (Equador). 60 A REBRIP - Rede Brasileira Pela Integração dos Povos acompanha e incide sobre a política externa brasileira desde 2001. Somos um coletivo integrado por entidades sindicais e associações profissionais, movimentos sociais, camponeses, de mulheres, ambientalistas e ONGs autônomas e pluralistas, que busca influenciar as negociações de comércio internacional e os processos de integração regional. Estamos comprometidos com a construção de uma sociedade democrática pautada no desenvolvimento ético, justo e ambientalmente sustentável, e atuamos em articulação com redes latino americanas e globais. REDE BRASILEIRA PELA INTEGRAÇÃO DOS POVOS. Institucional. Disponível em: http://www. rebrip.org.br/institucional/. Acesso em: 07 dez. 2016. 
De igual modo, verificou-se a transnacionalidade das diretivas europeias no contexto do direito administrativo global, haja vista o caráter uniformizador/harmonizador que esta norma europeia possui, fazendo com que se crie um padrão normativo a ser seguido pelos Estados-Membros. Desse modo, sendo o Parlamento Europeu e o Conselho da União Europeia órgãos de regulação global, é possível dizer que as diretivas europeias podem ser consideradas como uma fonte normativa do direito administrativo global, com repercussão extrabloco.

Isso se completa com do caso apresentado WT/ DS 409, Confisco de medicamentos genéricos em contraposição aos Direitos de Propriedade Intelectual. Foi possível verificar que a existência da Diretiva Europeia n.48 estabeleceu um padrão de proteção destes direitos, impedindo o tráfego de medicamentos genéricos da Índia para Brasil de forma continuada. A repercussão global da diretiva europeia se mostra a partir do momento em que se leva a reclamação à OMC e a demanda no Tribunal Permanente dos Povos, refletindo em diversos países da América Latina, como o Brasil.

Constatou-se, portanto, que o direito administrativo global por ser um órgão de regulação administrativa, possuindo uma diversidade institucional, jurisdicional e normativa, as diretivas europeias dão origem a um regime de accountability entre os Estados-Membros, primeiramente com foco na regulação botton-up (debaixo para cima), uma vez que há a participação na administração global na ampliação e adaptação dos instrumentos de direito administrativo nacional. Por outro lado, as diretivas europeias, em algumas situações, como no caso apresentado, podem realizar regulação top-down (de cima para baixo), o que significa dizer que o de padrões, decorrentes das diretivas, refletem no plano internacional ou até mesmo em outros ordenamentos jurídicos nacionais alheios ao da União Europeia.

\section{REFERÊNCIAS BIBLIOGRÁFICAS}

\section{CANOTILHO, J. J. Gomes. Direito Constitucional e teoria da constituição. Coimbra: Almedina, 2015.}

CASSESE, Sabino. Il diritto globale: giustizia e democrazia oltre lo Stato. Torino: EINAUDI, 2009.

CHITI, Edoardo. GAL and EU administrative law: A research agenda. In: CASSESE, Sabino et. al. (Org). Global Administrative Law: An Italian Perspective. 2012. p. 81-86. Disponível em: <http://cadmus.eui.eu/ bitstream/handle/1814/22374/RSCAS_PP_2012_04. pdf ? sequence $=1$ \&isAllowed $=y>$. Acesso em: 07 dez. 2016.

CHITI, Edoardo; MATTARELLA, Bernardo Giorgio. Introduction: The Relationships Between Global Administrative Law and UE Administrative Law. In: CHITI, Edoardo; MATTARELLA, Bernardo Giorgio (Ed.). Global Administrative Law and EU Administrative Law: Relationships, Legal Issues and Comparison. Berlin: Springer-Verlag Berlin Heidelberg, 2011.

DELMAS-MARTY, M. Le pluralisme ordonné et les interactions entre ensembles juridiques. 2006. Disponível em: $<$ http://www.ieim.uqam.ca/IMG/pdf/article_Dalloz. pdf $>$. Acesso em: 7 jul. 2015.

DUARTE, Maria Luísa. União Europeia e direitos fundamentais: no espaço da internormatividade. Lisboa: AAFDL, 2013.

ENLAZANDO ALTERNATIVA. Empresas transnacionais europeias na América Latina: estudo de caso de transnacionais farmacêuticas no Brasil. 2008. Disponível em: <http://www.enlazandoalternativas.org/IMG/pdf/5POR.pdf>. Acesso em: 15 jul. 2015.

GROSSMANN, Elias. Paz e República Mundial: de Kant a Höffe. Tese (Doutorado) - Faculdade de Filosofia e Ciências Humanas da Pontifícia Universidade Católica do Rio Grande do Sul, Porto Alegre, 2006. Disponível em: <http://tede.pucrs.br/tde_busca/arquivo.php?codArquivo=324>. Acesso em: 07 jul. 2015.

HENNEBEL, Ludovic. Penser le droit administratif global. In: BORIS, Clementine. Un droit administratif global? Cahiers Internationaux - CEDIN, Naterre: Pedone, 2012. p. 78-79.

ICTSD. Apreensões de medicamentos genéricos e a condenação da UE no Tribunal Permanente dos Povos. 2010. Disponível em: <http://www.ictsd.org/bridges-news/ pontes $/$ news / apreens $\%$ C $3 \%$ B 5 es-de-medicamentosgen $\% \mathrm{C} 3 \% \mathrm{~A} 9$ ricos-e-a-condena $\% \mathrm{C} 3 \% \mathrm{~A} 7 \% \mathrm{C} 3 \% \mathrm{~A} 3 \mathrm{o}-$ da-ue-no-tribunal>. Acesso em: 14 jul. 2015.

KINGSBURY, Benedict; KRISCH, Nico; STEWART, Richard B. Anexxe: l'emergence du droit administratif global. In: BORIS, Clementine. Un droit administratif global? Cahiers Internationaux - CEDIN, Naterre: Pedone, 2012. 
KINGSBURY, Benedict; KRISCH, Nico; STEWART, Richard B. El surgimiento del derecho administrativo global. Revista de Derecho Público, Bogotá, n. 24, mar. 2010.

KINGSBURY, Benedict; KRISCH, Nico; STEWART, Richard B. The emergence of global administrative law. Law and Contemporary Problems, v. 68, p. 15. Disponível em: <http://scholarship.law.duke.edu/cgi/viewcontent.cgi?article $=1361 \&$ context $=\mathrm{lcp}>$. Acesso em: 10 jul. 2015.

KRISCH, Nico; KINGSBURY, Benedict. Introdução: governança global e direito administrativo global na ordem legal internacional. Revista de Direito Administrativo, Rio de Janeiro, v. 261, p. 13-32, set./dez. 2012.

MARTINS, Clélia Aparecida. Algumas considerações sobre o Estado e Direito em Kant. Revista Perspectiva Filosófica, v. 4, n. 11, p. 63-64, jan./jun. 1999.

QUADROS, Fausto. A nova dimensão do direito administrativo. Coimbra: Almedina, 2001.

QUADROS, Fausto. Direito da União Europeia. Coimbra: Almedina, 2015.

RODRÍGUEZ, Libardo. El derecho administrativo transnacional o global: un nuevo capitulo del derecho administrativo. Disponível em: < http:/ / es.globallawpress.org/ wp-content/uploads/derecho-administrativo-globalnuevo-cap\%c3\%8dtulo-2015.doc>. Acesso em: 8 jul. 2015.

ROQUE, Miguel Prata. A dimensão transnacional do Direito Administrativo. Lisboa: AAFDL, 2014.

SANCHEZ BADIN, Michelle Ratton. The Global Administrative Law Project. a review from Brazil. 2008. Disponível em: <http://ssrn.com/abstract=1483379>. Acesso em: 21 jul. 2015.

SANTOS, Leonel Ribeiro dos. Kant: da reinvenção do Republicanismo à ideia de uma "República Mundial". Cadernos de Filosofia Alemã, n. 16, p. 13-54, jul./dez. 2010.

SILVA, Suzana Tavares da. Sumários desenvolvidos Direito Administrativo $2^{\circ}$ ciclo (2 ${ }^{a}$ Turma). Disponível em: <www. estig.ipbeja.pt/ ac_direito/SuzanaAdm.pdf $>$. Acesso em: 10 dez. 2014.

SLAUGHTER, Anne-Marie. Sovereignty and Power in a Networked World Order. 40 Stan. J. Int'l L. 283. Disponível em: <https://www.law.upenn.edu/live/ files/1647-slaughter-annemarie-sovereignty-and-power-in-a> . Acesso em: 21 jul. 2015.

TRIPATHI, Rajeshwar. Concept of global administrative law an overview. India Quarterly: A Journal of International Affairs, v. 67, p. 355, 2011. Disponível em: $<$ http://iqq.sagepub.com/content/67/4/355>. Acesso em: 8 jul. 2015.

VARELLA, M. D. Internacionalização do Direito: Direito Internacional, Globalização e Complexidade. Brasília: Uniceub, 2012.

VILAÇA, José Luís. A propósito dos efeitos das directivas na ordem jurídica dos Estados-membros. Justiça Administrativa, n. 30, nov./dez. 2001. Disponível em: <www.fd.unl.pt/docentes_docs/ma/np_MA_15752. pdf>. Acesso em: 15 jul. 2015.

VILAÇA, José Luís. Directivas Comunitárias. 2010/2011. Elaborado por MAN TENG IONG. Disponível em: $<$ http://www.fd.unl.pt/docentes_docs/ma/jlcv_ MA_12764.pdf>. Acesso em: 15 jul. 2015.

WESSEL, Ramses A.; WOUTERS, Jan. The Phenomenon of Multilevel Regulation: Interactions between Global, EU and National Regulatory Spheres. Disponível em: <http://www.utwente.nl/bms/pa/research/wessel/ wessel44.pdf $>$. Acesso em: 10 dez. 2015.

WORLD TRADE ORGANIZATION. European Union and a Member State: Seizure of Generic Drugs in Transit (WT/DS 409). 2010. Disponível em: <https://www. wto.org/english/tratop_e/dispu_e/cases_e/ds409_e. htm>. Acesso em: 10 jul. 2015.

WORLD TRADE ORGANIZATION. Trade-Related Aspects of Intellectual Property Rights (TRIPS). Disponível em: <https://www.wto.org/english/docs_e/ legal_e/27-trips_01_e.htm>. Acesso em: 15 jul. 2015. 
Para publicar na Revista de Direito Internacional, acesse o endereço eletrônico www.rdi.uniceub.br ou www.brazilianjournal.org.

Observe as normas de publicação, para facilitar e agilizar o trabalho de edição. 